\author{
Anna Mikulska \\ Jagiellonian University, Krakow, Poland \\ anna.mikulska@doctoral.uj.edu.pl
}

\title{
Chinese Migration in Poland - an Attempt to Characterize the Migrant Group, Including the Cultural and Educational Perspective of the Young Generation
}

\begin{abstract}
This article presents selected examples related to everyday school life as experienced by one generation of Chinese immigrants in Poland. Apart from a theoretical framework, the statements and research questions were supported by empirical evidence showing that the process of acquiring Polish language and cultural norms may be a more complex challenge for Chinese immigrants in comparison to other immigrant groups in Poland.
\end{abstract}

Keywords: Chinese in Poland; cultural differences; language interference; teaching Polish as a foreign and second language

\section{Historical Context, Group Size and Place of Residence}

In recent years, Chinese outward migration has been growing. In the case of Poland, this phenomenon became noticeable after its accession to the European Union $^{1}$ in 2004. According to Wardęga (2017, p. 124), Chinese people have recently become the seventh-largest ${ }^{2}$ minority group in Poland.

Nevertheless, it is difficult to estimate the exact number of Chinese citizens in Poland. This is due to the fact that many Chinese citizens come to Poland from other Central European countries, especially from Hungary, Italy and the former Yugoslavia. Jóźwiak et al. (2013, p. 47) highlighted that entrepreneurs in particular are constantly travelling within the Schengen area. According to research data, in 2019 more than 8,400 citizens of Chinese origin had the right to live in Poland (permanently or temporarily) and this number is estimated to still be increasing. ${ }^{3}$

The first immigrants from China settled in Poland in the 1950s and lived mainly in the Tri-city area (Gdańsk-Sopot-Gdynia in northern Poland). The reason for choosing this area was related to the existence of the Chinese-Polish Joint Stock Shipping Company (Chipolbrok). ${ }^{4}$ In the 1980s

\footnotetext{
${ }^{1}$ A month after Poland's accession to the EU, the country was visited by the chairman of the People's Republic of China, Hu Jintao. It is believed that since that time there has been an increase in interest in Poland among Chinese businessmen (more see: Wardęga, 2016).

2 After Ukrainians, Belarusians, Germans, Russians, Vietnamese and Italian citizens.

${ }^{3}$ Data taken from the Office for Foreigners, Figures for proceedings against foreigners in 2019 (Urząd do Spraw Cudzoziemców, n.d.).

${ }^{4}$ Chipolbrok was the first joint venture of The People's Republic of China. Starting with 6 old vessels, Chipolbrok has now developed into an ocean shipping corporation with net assets of over USD 300 million, a fleet of 17 professional heavy lift vessels boasting a total capacity of nearly 496,000 DWT, and liners reaching all major global harbours. (more: http://www.chipolbrok.com.pl/; Chinese-Polish Joint Stock Shipping Company Chipolbrok, n.d.).
} 
and 1990s, other groups of well-educated Chinese newcomers decided to start businesses in Poland, cooperating with other companies in Central and Eastern Europe. Since the late 1990s, Chinese migration has mainly consisted of contract workers employed in gastronomy, construction, Chinese medicine centres and Eastern martial arts schools. However, it should be noted that this tendency has changed recently. Due to greater mobility, Chinese citizens have become more integrated into European societies and economies as they better understand the working and living conditions in Europe. This has resulted in some finding well-paid jobs (Wardęga, 2016, p. 294).

As is the case in other East-Central European countries, Chinese immigrants in Poland mostly settle in the capital and other large cities. The following areas are particularly related to their entrepreneurial activities:

- Lesznowola municipality (near Warsaw) - Chinese Shopping Center (GD),

- Jaworzno (southern Poland) - Chinese Wholesale Trade Center,

- Tri-city (Gdańsk-Gdynia-Sopot agglomeration), associated with the Chipolbrok company,

- the surroundings of Kraków, Bydgoszcz and Stalowa Wola.

It is worth mentioning that there are not yet any official "Chinatown" districts in Poland as there are in Western Europe and the United States. However, there are few housing estates such as "Park Agat" in Wólka Kosowska, "Park Szcześliwicki" or "Osiedle za Żelazną Bramą" in Warsaw, in which the number of residents may presumably increase in the near future.

\section{Aims of Chinese Migration to Poland}

Chinese investors appeared in Poland in the early 1990s and imported products (mainly textiles) to the Polish market. Recently, there has been increasingly more Chinese investment. A bilateral strategic partnership was officially announced in 2011. A year later, during the visit of Prime Minister Wen Jiabao to Poland, Chinese investors interested in launching businesses in Central and Eastern Europe received a special credit line to start their companies. As a result, several Chinese companies have opened branches or operations in Poland. Examples include Beijing West Industry Group in Krakow, Huawei Device Polska in Warsaw, Liugong Group in Stalowa Wola, Bank of China, and Industrial and Commercial Bank of China (ICBC). ${ }^{5}$

The growing Chinese interest in Poland is not only related to business or tourism. Chinese citizens are also moving to Poland for educational reasons. A Polish-Chinese partnership at the university level was initiated in China in 2011 during the visit of the then President of the Republic of Poland, Bronisław Komorowski. The agreement concerned scholarship exchange opportunities for students and scientists, as well as joint scientific research. Additionally, the document supported the promotion of teaching Polish in China and Chinese in Poland, by means of launching new university units and educating future sinologists in Poland and Polish language teachers in China (Wardegga, 2016, p. 291).

Nevertheless, many Chinese students usually return to their homeland or continue their studies in English-speaking countries. Returning home may be perceived as a patriotic action which enables them to achieve greater social prestige within Chinese society. Chinese people studying abroad are considered to be young ambassadors, who have foreign language skills and have gained experience in the international environment. As a result, they may enjoy better job prospects because being a desirable employee enhances opportunities to develop their professional career (Wardęga, 2017, p. 135).

${ }^{5}$ The first branch in Central and Eastern Europe was established in Poland in 2012. 


\section{Types of Groups and Cultural Activities Within the Chinese Immigration Group}

Despite the fact that the number of Chinese immigrants in Poland is still relatively small, there are several registered and active cultural organizations. The oldest is the Polish-Chinese Friendship Society, founded in the 1950s. The organization associates mainly Poles and Polish-Chinese families. From its very beginning, its aim has been to organize cultural events (concerts, film screenings, exhibitions and meetings with famous writers). The next institution which facilitates and maintains ties among Chinese citizens in Poland is the Embassy of the People's Republic of China. It is the place where the older generation of immigrants meet regularly and have an opportunity to talk and to exchange experiences and information regarding, for instance, employment or solving issues with the Polish legal system. Other organizations involved in maintaining tradition and culture are the "Chopin" Polish Foundation for Cultural Exchange ${ }^{6}$ and the Polish-Chinese Association for Culture and Art. ${ }^{7}$

In terms of economic issues, the major institutions responsible for assisting in the development of Polish-Chinese economic contacts, acquiring new partners, organizing meetings and business conferences, and exchanging experience in both markets are the Chinese Chamber of Commerce ${ }^{8}$ and the Polish-Chinese Economic and Cultural Association.

In addition, the Chinese willingly promote not only their culture but also their language. Chinese language courses are offered at five Confucius Institutes in Poland (in Kraków, Opole, Poznań, Wrocław and Gdańsk ${ }^{9}$ ). These centres not only bring together academic staff and Polish students who want to learn Chinese, but are also places where traditional celebrations like Chinese New Year or the Spring Lantern Festival are organized. Moreover, Confucius Institutes in Poland also operate Hanyu Shuiping Kaoshi $\left(\mathrm{HSK}^{10}\right)$ and Youth Chinese Test (YCT) exam centres.

\section{Cultural Differences}

\subsection{Attitude and Manners}

There are meaningful differences between Chinese and European culture, including Polish culture. Differences in terms of the behaviour and manners considered acceptable may lead to misunderstandings and stereotypes.

An important issue in Chinese culture is the concept of saving and losing face. It is associated with one's moral attitude, reputation and good name. Wardegga (2016, p. 328) explains that in Chinese there are two meanings of the word face. The first - liăn ${ }^{11}$ is a moral character and the second - nam - expresses the social status of a person. "Keeping face" can be translated as maintaining one's honour and dignity, as well as one's position in society. In turn, "losing face" can result in exclusion from the social group. This occurs when, for instance, a person is humiliated in public or loses his temper in a particular situation. One can also "recover face" by means of sacrificing oneself for others or offering them help. In order to maintain harmony, which is essential according to Confucian teachings, the Chinese avoid confrontation or conflict with

\footnotetext{
${ }^{6}$ This organization was founded in Krakow in 2013 by a Chinese entrepreneur and musician; its goal is to support Chinese artists and organize their concerts in Poland.

7 A non-governmental organization founded in Wrocław in 2012. Its activity is focused on promoting Chinese culture in Poland and Polish culture in China; its task is also to support the integration of both countries (http://www. chinapolandart.org/).

${ }^{8}$ For more details see: http://pchig.pl

9 There are about 540 branches of the institute around the world.

10 The Chinese Proficiency Test (Hanyu Shuiping Kaoshi) is a test prepared by the HSK Center of the Beijing University of Culture and Language. It verifies proficiency in Mandarin language and is recognized worldwide.

11 The entries in Chinese are given in transliteration.
} 
each other. Therefore, they have difficulties with assertiveness, refusal or expression of their fears because they consider it a sign of bad behaviour.

One of the most typical personality traits for the Chinese is restraint, which is a fundamental principle of savoir-vivre. Accordingly, a well-mannered person should be calm and be able to control his/her emotions. The conviction that emotionalism is a sign of immaturity causes many Chinese family members to behave with reserve and distance not only towards strangers but also towards each other. They may be convinced that by means of hiding emotions, they do not "lose face" in any situation (Wardęga, 2016, pp. 323-330).

Wardęga (2016) adds that there are also slight differences in maintaining physical distance during conversation; in Asia this distance is generally smaller ${ }^{12}$ than in European circumstances. In addition, Chinese people will intentionally avoid eye contact and may usually speak a little louder than Polish people.

It is worth mentioning that in comparison to Western culture, in China a person is defined much more by her/his position and role in society. Each of these function has a special name. As a results, by means of using labels such as laoshi, ${ }^{13}$ and shifu, ${ }^{14}$ somebody is placed in a certain hierarchy. In this way, people in China emphasize official or unofficial types of relation (Malejka \& Gang, 2010, p. 59). Moreover, Chinese documents usually provide a surname before the first name. In turn, during conversation Chinese people use a full name when they address the recipient, even if they are very close to each other, such as husband and wife (Malejka \& Gang, 2010, p. 62). ${ }^{15}$

\subsection{Public and Private Life}

China (Zhōngguó) literally means the Middle State. The perception of China as the centre of the world functioned in the minds of its citizens for a long time. In turn, The Great Wall of China was a symbol of the protection of the Chinese world and its separation from barbarian foreigners. The importance of privacy and safety is also visible in urban architecture. Traditional Chinese households were called sihéyuàn owing to their special building style. Their function was to safeguard against any outside danger (Wardęga, 2016, p. 323).

While protecting themselves against external danger, the Chinese tend to pay attention to fostering good professional relationships between colleagues and family members. The reason for this behaviour may be a collectivist conviction to take care of and to protect the interests of the group as an entity. The word guānxi means the relationships and interrelationships between individual group members which have been built up and shaped for many generations. Its foundation is kinship, strong national identification, and the crucial impact of the family on everyday life (Sidorowicz, 2014, p. 53). Therefore, having a network of proven and trusted relations, based mainly on family ties, is a crucial feature characterizing Chinese society.

Morever, guānxi also refers to the concept of good, intentionally shaped relationships in business dealings/issues. It can be seen as a form of ubiquitous interaction networking which the Chinese do in order to have long-term connections and successful contacts, both in private and professional life (Sidorowicz, 2014, p. 53).

Guānxi includes four main principles: benefit (rénqíng), face (miànzi), reciprocity, and ethics. The first refers to the spirit and emotions. Rén means to devote oneself and one's life to the general good of humanity, while qing means sentiment, favour, kindness and good relationships with others. This term, according to Sidorowicz (2014, p. 54), is used when congratulating somebody or giving someone a gift, but also when offering condolences at a funeral. Rénqing means that when somebody has received some type of good or benefit from someone else, he or she should

\footnotetext{
${ }_{12}$ More or less the length of a hand from an interlocutor.

13 Eng. teacher.

14 Previously: former master craftsman; today is it called a person with a lower social profession like taxi driver, hairdresser or waiter. For more details see: Malejka \& Gang, 2010.

${ }^{15}$ For more information about how the Chinese perceived themselves as a nation — see: Malejka, 2008.
} 
do or give something similar in return. Giving and receiving any kind of kinship, including words, behaviour and gifts, is a kind of reward which has a deep meaning in Chinese culture and is more significant in comparison to other cultures.

On the other hand, the Chinese word (miànzi) concentrates on the individual's position in society, which is associated with honour and prestige. These, in turn, are achieved through success, including in professional life (Sidorowicz, 2014, p. 55). Good relations with others are also based on reciprocity. (Guānxi) reveals itself through individual and emotional responses to help received from others, as well as mutual exchange interests and favours between people.

The last part of the guānxi concept is the Chinese way of offering gifts. From a Chinese perspective, giving gifts is a very significant matter. An example of this behaviour is when somebody asks his/her boss for a favour at work and expects support in return. It is common for the Chinese to offer gifts at weddings, on Chinese New Year, or on other special occasions. The value of the gift depends on the relationship between the giver and the recipient. The closer the relationship is, the greater is the gratitude that should be expressed in the gift (Sidorowicz, 2014, pp. 55-56).

\subsection{Views on Education and Future/Adult Life}

Rowiński and Pawłowski (2011, p. 11) argue that in Chinese tradition, the family is treated as the foundation of a harmonious society. The younger generation derives wisdom and life experience from its elders, especially from grandparents. In turn, parents convey the values and rules of behaviour to children and they also have the right to enforce strict discipline. These observations are similar to a statement indicated earlier by Auyeung and Sands (1996, p. 267), who said that the transfer of knowledge from one generation to another is considered to be one of the main ways of educating society and maintaining the sustainability and strength of the group. Therefore, Chinese youth growing up in a multigenerational family are taught from the very beginning to think in terms of "we" rather than "I", preferring to choose the common good over their own. ${ }^{16}$

Home relations also have a significant impact on education. The desire to achieve prosperity and prestigious social status means that values such as diligence, determination, a sense of responsibility and the spirit of competition are instilled into Chinese youth from their earliest school years. In fact, there are good conditions for creating such a competitive atmosphere classes in Chinese schools are numerous and classrooms are usually large; hence, the teacher needs to be strict and demanding in order to teach successfully. In turn, students have to be motivated and persistent in order not only to receive good marks but also to have a chance to be better and to be distinguished from their peers.

It should be emphasized that the approach to teaching and teachers' attitudes are also quite different in China compared to Europe. Education in China is centrally organized and students consider teachers to be mentors and leaders who transfer knowledge and teach how to perceive the world and the surrounding reality. When reading texts, students usually receive instructions about how they should understand the context. As a result, young Chinese people are able to give specific answers to questions, but without their own assessment. Chinese students may therefore have difficulties in expressing their opinions and participating in teamwork or in class discussions. In contrast, passivity or lack of participation in a lesson are usually considered a sign of laziness and lack of ambition in Western culture (Henze \& Zhu, 2012; Thøgersen, 2016). Chinese students are often perceived as silent, passive listeners who do not have their own opinion and who take everything the teacher is as unquestionable. However, there is also another reason for this behaviour, resulting from another cultural factor. Many Asians do not share their points of view in class because of group hierarchy, and fear of making a mistake and feeling embarrassed in front of their peers and teacher. Moreover, from the students' point of view, they should not voice their own personal opinion because they perceive themselves as a part of the classroom community.

\footnotetext{
16 This is also in accordance with Confucianism, which prioritizes the common good and social harmony over individual interests (see more: Zhang et al., 2013).
} 
Therefore, Chinese students are unaccustomed to giving an answer unless a teacher points to them and asks directly.

Another typical feature of Chinese education is assessment. Hanwei $(2017$, p. 89) states that knowledge is mainly verified through written tests, often with multiple choice questions. In turn, oral exams are rarely taken. This may explain why oral presentations and classwork in front of peers may be a truly difficult and serious challenge for Chinese students attending European schools.

Teaching methods are another significant factor. The Chinese prefer individual to group work during lessons. The reasons for this are most likely the aforementioned rivalry for best marks and the instilled faith in the importance of independent work through which they can accomplish success. ${ }^{17}$ In addition, Chinese youth are followers of rote learning, ${ }^{18}$ which is closely connected with the Confucian tradition. Unlike Europeans, who may perceive this way of learning as mindless repetition, the Chinese believe that learning by heart can contribute to better comprehension and an attempt to reflect on what has been already learned and how it can be combined with prior knowledge (Li \& Cutting, 2011, p. 93).

However, it should be emphasized that education in China is gradually transforming. Examples of these changes include the introduction of activating teaching methods which encourage Chinese students to work in groups and master communication skills, as well as think more creatively. These steps may be viewed as the potential beginning of unifying teaching in the XXI century. ${ }^{19}$

\section{The Presence of Chinese Pupils in Polish Schools: Research}

Due to the fact that Chinese migration to Poland has taken the form of family migration, the Polish school system has been welcoming more and more students with from a Chinese cultural background. In comparison to Ukrainians ${ }^{20}$ for instance, the number of Chinese children in Polish schools is still small. However, because of an entirely different set of cultural and moral values, youth from Asian backgrounds struggle and experience adversity in everyday school life.

The purpose of this paper is to present and consider selected characteristics of teaching Polish as a foreign language to children who come from different countries and cultures. These difficulties are caused by three main factors - linguistic, cultural and educational - which often hamper the opportunities to communicate and integrate (Mikulska, 2016, 2019b). These barriers also pose a challenge for teachers - if communication and understanding cannot be achieved, learning cannot be facilitated.

The following part of the paper constitutes an attempt to answer two research questions:

1. What are the examples of mistakes made by Chinese students in their writing and what is the possible reason for these grammatical errors?

2. What are the symptoms of culture shock among Chinese students attending Polish schools?

Firstly, the paper will focus on selected language mistakes which students have made during written work. Secondly, several cases which took place during classes will be analysed as examples

${ }^{17}$ However, group activities are beneficial for them - they provide an opportunity to integrate. Chinese students are also accustomed to having a vast amount of homework, which is actually expected and welcomed (Parris-Kidd \& Barnett, 2011, p. 175).

18 Rote learning starts in kindergarten, learning how to write Chinese characters.

19 Similarly to European education, in China there is also a trend for promoting Lifelong Learning Programs. This was emphasized in the speech given by the Minister of Education in the People's Republic of China, Zhang Xinsheng at the ASEM conference in Beijing on November 27, 2008 (Zhang, n.d.).

ASEM (Asia-Europe Meeting) is an agreement created in 1996 aimed at supporting dialogue and cooperation between Asia and Europe. ASEM deals with political, economic, social, cultural and educational issues in a spirit of mutual respect and equal partnership. https://www. aseminfoboard.org/.

${ }^{20}$ For more details about Ukrainian migration in Poland see: Levchuk, 2019. 
of how cultural differences between Polish and Chinese standards of behaviour may be misleading and cause crisis situations in a school environment.

It should be emphasized that this research is only a part of the broad academic interest related to teaching Polish as a foreign and second language to Chinese students. Nevertheless, it indicates a significant issue and may help begin the discussion regarding what solutions should be introduced in order to help and better support students from different cultures during their adaptation in Polish schools.

\subsection{The Language Barrier}

Method In order to ascertain what kind of difficulties Chinese students have with learning Polish, the author of this article collected students' work. The following data comes from a corpus of texts which were written during classes in Polish as a foreign and second language. They comprise mainly of expository and persuasive writings related to school reading books.

The research was carried out from March 2018 to June 2018 at a primary school near Warsaw. The participants were chosen based on precise features: similar age, country of origin, and the time of arrival in Poland with their parents. As a result, the study group consisted of 12 students - 7 girls and 5 boys of Chinese origin. Apart from one 14-year-old teenager, all participants were aged 11 to 13 at the time of the study. Furthermore, each of the young Chinese pupils, with the exception of one, had already been living in Poland for over a year. ${ }^{21}$

Generally, the corpus was analysed based on the assumption that the language mistakes were made because of the significant differences between Chinese and Polish. However, the data does not provide information regarding spelling, lexical, and punctuation difficulties. ${ }^{22}$ The examples illustrate only a part of the wide and complex problem of interference which requires further research. ${ }^{23}$

Findings Table 1 shows examples of selected linguistic mistakes made by Chinese students:

As can be seen in Table 1, the most common mistakes that appeared in the writings resulted from the significant typological differences between the native (Chinese) and the target (Polish) language. This may be the result of strong interference and negative transfer.

In the abovementioned examples, students have difficulties with verb conjugation, did not maintain verb tense consistency and used wrong or missing inflected endings in Simple Past tense. Additionally, they had difficulties in declining Polish nouns and adjectives.

Nevertheless, it is noteworthy that some of the errors suggest an incomplete acquaintance with the inflection paradigms (noun, verb, adjective) and insufficient knowledge of Polish grammar usage.

\subsection{The Cultural Barrier}

Method There is an underlying assumption that culture has a significant impact on shaping a person's identity and character. This particular system of values, manners and customs can help one to adjust to a new place, to gain courage and to make new friends. However, cultural differences can sometimes cause unpleasant situations. They may also have serious effects, including culture shock. ${ }^{24}$ The Chinese students experienced this during their first two years of learning in the

${ }^{21}$ The average length of stay in Poland was $2-2.5$ years.

${ }^{22}$ Difficulties regarding pronunciation among Chinese students was a subject of Młynarczyk's work (Młynarczyk, 2013).

23 All data comes from the research collection made by the author of this paper. They are excerpts from the dissertation "Chinese students in the Polish education system — from basic communication skills to cognitive academic language proficiency" (in the process of writing/preparing).

${ }^{24}$ For more details see: Oberg, 1960. 
Table 1. Examples of languages mistakes vs. appropriate forms of sentences in Polish.

\begin{tabular}{|c|c|c|}
\hline & Example of linguistic mistakes & Correct/appropriate form \\
\hline \multicolumn{3}{|c|}{ Morphological errors } \\
\hline $\begin{array}{l}\text { a. Difficulties in } \\
\text { verb conjugation }\end{array}$ & $\begin{array}{l}\text { Kiedy leżyć na plaży, styszeć fale. } \\
\text { Polacy poznaje dobrze historia. } \\
\text { Podsumowujac moge powiedzieć. }\end{array}$ & $\begin{array}{l}\text { Kiedy leże na plaży, stysze fale. } \\
\text { Polacy poznaja dobrze historie. } \\
\text { Podsumowujac moge powiedzieć. }\end{array}$ \\
\hline $\begin{array}{l}\text { b. Difficulties in } \\
\text { verb tense con- } \\
\text { sistency }\end{array}$ & $\begin{array}{l}\text { Myśliwy nie chce zabić królewna, więc } \\
\text { kazat jej ucieka, } \\
\begin{array}{l}\text { Jak idziemy na wycieczka to zawsze nosit } \\
\text { stuchawki, }\end{array}\end{array}$ & $\begin{array}{l}\text { Myśliwy nie chciat zabić królewny, więc } \\
\text { kazat jej ucieka[ć], } \\
\text { Jak idziemy na wycieczke to [on] zawsze } \\
\text { nosi stuchawki, }\end{array}$ \\
\hline $\begin{array}{l}\text { c. Wrong or miss- } \\
\text { ing inflected end- } \\
\text { ings (using verbs } \\
\text { in Simple Past) } \\
\end{array}$ & $\begin{array}{l}\text { Potem poszedliśmy na Stare Miasto. } \\
\text { Nowy kolega weszedł do sali. }\end{array}$ & $\begin{array}{l}\text { Potem poszliśmy na Stare Miasto. } \\
\text { Nowy kolega wszedt do sali. }\end{array}$ \\
\hline \multicolumn{3}{|c|}{ Syntax errors } \\
\hline $\begin{array}{l}\text { a. Lack of famili- } \\
\text { arity with Polish } \\
\text { noun declension }\end{array}$ & $\begin{array}{l}\text { On ma } 30 \text { lat i mieszka w Warszawa. } \\
\text { Ona nie lubi grać w oszykówka i siat- } \\
\text { kówka. } \\
\text { Oni maja jedna siostra i jeden brat. } \\
\text { Na zdjęciu dziewczyna robi praca domowa } \\
\text { z angielskiego. } \\
\text { Basia jest bardzo mita dla wszyscy. } \\
\text { "Pan Tadeusz" jest obowiazkowa lektura } \\
\text { szkolna. } \\
\text { Wiele ludzi uczy się ta ksiażka na pamięć. }\end{array}$ & $\begin{array}{l}\text { On ma } 30 \text { lat i mieszka wirszawie. } \\
\text { Ona nie lubi grać w koszykówke i siat- } \\
\text { kówke. } \\
\text { Oni maja jedna siostre i jednego brata. } \\
\text { Na zdjęciu dziewczyna robi prace domowa } \\
\text { z angielskiego. } \\
\text { Basia jest bardzo mita dla wszystkich. } \\
\text { "Pan Tadeusz" jest obowiazkowa lektura } \\
\text { szkolna. } \\
\text { Wiele ludzi uczy się tej ksiażki na pamięć. }\end{array}$ \\
\hline $\begin{array}{l}\text { c. Wrong or miss- } \\
\text { ing prepositions } \\
\text { (from phrases } \\
\text { preceding a noun } \\
\text { or noun phrase) }\end{array}$ & $\begin{array}{l}\text { (...) ogladat telewizje o godzina } 17.00 \text { do } \\
\text { 18.00. } \\
\text { Ona teraz siedzi na sali i sprawdza kart- } \\
\text { kówki. } \\
\text { Mogtem widzieć wszystko pod okniem z } z \\
\text { góry. } \\
\text { Myśliwy kazat schować sie do lasa. } \\
\text { Mój kolega chodzi w jednej klasie ze mna. }\end{array}$ & $\begin{array}{l}\text { (...) ogladat telewizje od godziny } 17.00 \text { do } \\
\text { 18.00. } \\
\text { Ona teraz siedzi w sali i sprawdza kart- } \\
\text { kówki. } \\
\text { Mogłem widzieć wszystko przez okno z z } \\
\text { góry. } \\
\text { Myśliwy kazal schować sie } \underset{\sim}{\text { w lesie. }} \text {. } \\
\text { Mój kolega chodzi do jednej klasyूze mna. }\end{array}$ \\
\hline
\end{tabular}

Polish school. The next part of the research is based on interviews with a cultural assistant ${ }^{25}$ and an intercultural psychologist who were working at the school at that time. The author of the paper spoke with them separately. The interviews were conducted in June 2018 and contained several questions regarding the students' attitudes and manners during lessons. The questions were prepared in advance and they focused mainly on the cultural assistant and intercultural psychologist's own perspectives regarding the students' adaptation to the school.

Findings The answers received from both interviewees confirmed that the students from Chinese backgrounds struggled to cope with cultural differences, which resulted in variety of behaviours that might limit their learning opportunities. The first problem was the withdrawn and quiet attitude of the students:

${ }^{25}$ A cultural assistant is a person who speaks students' native language (here Chinese) but also knows the specificity of generally accepted behaviour for both cultures - Polish and Chinese. His/her role is to support students and enable them to adapt more easily at school. The language help offered by them is also very helpful for parents who often do not speak Polish at all. A cultural assistant can be hired by a school principal based on Polish law since 2016 . 
I remember that the students tended not to speak up during lessons so as not to be noticed, because then they would have to initiate contact/conversations, which was the most difficult thing for them. They hardly ever asked for help because it meant they would have to explain what their problem was. Therefore they prefer to stay back and be silent.

This example confirmed one of the aforementioned Chinese features of character - being quiet and obedient. The students were unaccustomed to answering the teacher's questions unless they were asked directly. Moreover, their conviction of being a member of the classroom community required them not to share their personal opinions in class. Above all, they were afraid of making a mistake and consequently feeling embarrassed, due to the fear of "losing face" - typical for a collectivist culture. Secondly, the frustration caused by the lack of understanding often led to aggressive incidents and bullying:

Aggression and uncontrolled emotions happened during lesson breaks. They were a reaction to provocation from the Polish students.

Other symptoms of cultural shock were abdominal pain, crying, and chronic self- destruction disorders (hair extraction and nail biting):

One of my students represents a difficult case of a boy who has been destroyed from the inside by acculturation stress. The effect of this was not only withdrawal but also nervous behaviours...I can say even disorders such as pulling hair from the head, grey hair or biting nails. Can you imagine a greying teenager? I saw it for the first time with him. This is an example of a sensitive boy who, instead of exposing his frustration and anger related to the language barrier or other cultural norms, suppressed the negative emotions within himself. The evidence for this are his self-destructive actions.

The interviews also indicated that the expectations the teachers and school had for the students often led to a decrease in motivation or a lack of interest in learning:

(...) I first met him during additional Polish classes that we organized during the summer. He did not understand the instructions in Polish which made him very frustrated. Apparently, he was too ambitious. He did not want to understand that learning a language is a long process and that Polish is a difficult language. He was already a teenager so in September he started regular school and went to $5^{\text {th }}$ or $6^{\text {th }}$ Grade. It was already quite difficult for him to take part in regular classes, do homework and do exams. However, when he passed and went to rth $^{\text {th }}$ Gade he started to skip classes because there was too much core content from different subjects for him to study. The parents had no idea that something was wrong because they went to work every day and came back home late. The reason for the truancy was a mental breakdown. The teenager felt that he was unable to cope with education in Polish any more. The backlog of learning new things was getting bigger and bigger day by day and he did not want to ask for help. Luckily, I managed to convince him to return to school and support his education. Owing to help given by the teachers he caught up with his studies and passed the winter semester (...).

(...) In her home country she used to be a smiling, go-getting young girl who was eager to learn, play and compete. However, she suddenly started showing a reluctance to study and work. Her open-minded nature changed drastically after several months of schooling. She became withdrawn and stopped making progress in her learning. She was lonely at times, she did not want to spend time with others during breaks, not even with Chinese children. She was unable to accept praise, she ignored reprimands... I can say she even seemed rebellious. She often said, when emotional, "I don't care! I don't want to be in this school! I don't want to be in Poland..." I think that she has good language skills but she does not want to use them, because it involves effort, self-control and showing a willingness to fully participate in school life (...).

Both statements quoted above show the Chinese pupils' willingness to be diligent and hardworking students who are determined and ready to compete in order to accomplish the best results in exams. However, too many obstacles (including the language barrier) and excessive expectations on the part of the teachers may evidently lead to a loss of self-esteem and motivation to learn. 


\subsection{Discussion}

The premise of the present investigation is that the adaptation process for young Chinese immigrants in Poland is affected by language and cultural and educational factors. These obstacles undoubtedly impede the adaptation process in Polish schools.

The first aim of the research was to investigate what examples of language problems Chinese students encounter when learning Polish as a foreign language. Secondly, the author was particularly interested to determine whether young teenagers from China experience culture shock and if so, how it is manifested and how it affects their everyday school life.

The presented data, based on a corpus of Chinese students' written work and interviews with a cultural assistant and intercultural psychologist who worked with the students, reveals several intriguing patterns that may bear important implications for researchers and educators/ teachers.

\section{Research Question 1: What are the Examples of Mistakes Made by Chinese Students in Their Writing and what is the Possible Reason for These Grammatical Errors? By and large, Chinese students have problems with learning Polish because of the genetic and typological distance between the two languages. They have difficulties with understanding gram- mar, including name inflection, verb conjugation, and distinguishing between the types of noun and adjective crucial in Polish. The reasons for these difficulties are the significant differences in the languages' schematics. Polish displays regular accents, poly-syllabicity and inflexibility, while Chinese is characterised by tonality, mono-syllabicity and positioning.}

Research Question 2: What are the Symptoms of Culture Shock Among Chinese Students Attending Polish schools? Generally, culture shock among Chinese teenagers affected their well-being because it caused both withdrawal and, on the contrary, a rebellious and aggressive attitude among students who previously did not have any behavioural problems. Additionally, a few students experienced health problems (physically and mentally). In all cases, a confrontation with new customs led to a lessening of motivation or a lack of interest in learning Polish.

Taking the presented findings into consideration, it is possible to list several examples of good practices and solutions which can be introduced in order to help Chinese students to adapt more easily, more effectively and, most importantly, less stressfully to Polish schools.

Firstly, every multicultural school, when possible, should hire a cultural assistant who can support students and cooperate with the school faculty. The presence of cultural assistants undoubtedly has a positive impact on the adaptation process and decreases the culture shock experienced in the new school environment.

Secondly, students who come from distant countries need individualized learning and should receive more empathy from teachers. Academic standards have to be adapted to students' language capabilities. One example of a good method in teaching Polish as a foreign and second language is providing enough language drill exercises. This way of memorizing vocabulary and grammar rules is the best for rote learners - in this case Chinese students.

Moreover, teachers who conduct lessons should find out more about foreign students' culture in order to understand them better. Therefore, workshops and training sessions regarding teaching in a multilingual and multicultural class seem to be necessary in more and more schools in Poland.

\subsection{Limitations and Future Directions}

The current research utilized selected aspects of the broader issue of Chinese migration to Poland. Due to the fact that the focus was narrowed to a particular group, age and situation, it provides only a partial view of the topic. In order to unify it with similar research, there is a need to collect more data regarding, for instance, young adults or newcomers who have arrived in Poland and are studying at university with a lack of knowledge of Polish. Other interesting findings may be 
obtained while doing similar research on Chinese entrepreneurs who operated businesses in Poland and need to learn Polish on a communicative level. It would be a significant experiment to compare the results of their writings with the corpus compiled in this research. Moreover, if these students and entrepreneurs would be willing to share memories and feelings regarding their beginnings in Poland, they will conceivably bring another meaningful point to the scientific discussion in Polish Linguistics.

The proposed research, apart from its linguistic dimension, also provided insights into the possible effects of culture shock. The findings obtained from the interviews may be treated as evidence that there is a strong connection between learning a language, discovering new customs and cultural norms, and accomplishing a successful adaptation to a new school. Taking this into consideration, further study and ready solutions for educators should be established and considered in future research. Moreover, additional research replicating the current study is needed before it is possible to draw further conclusions whether this observation is unique or common among young migrants arriving from distant countries.

\section{Conclusions}

The People's Republic of China has transformed into a more progressive country and has become more open to the Western world, including Europe. One of the pieces of evidence for this statement is the growing Chinese migration to EU countries, including Poland.

The Chinese represent a collective type of society, which tends to care more about the good of the group than that of the individual. They are generally quiet, reserved people who avoid conflicts and confrontations. This attitude to life is in accordance with Confucian social philosophy which is, next to collectivism, a major factor shaping Chinese moral value systems.

The foundation of Chinese society is the family, which is highly hierarchical and also has a significant impact on education. Therefore, features of character typical for the Chinese are ambition, determination, diligence and obedience to teachers.

Difficulties in the adaptation process for Chinese students at Polish schools are caused by three main reasons: the language barrier, different school experiences gained from the Chinese education system, and cultural differences. The evidence for this statement is the research conducted in one school near Warsaw, where Chinese students constitute one group of foreign students.

The presented findings confirm that the adaptation process in Polish schools can be even more problematic for young immigrants who need to overcome complex obstacles. Although there are some regulations regarding teaching young immigrants in Poland (Majcher-Legawiec, 2017; Miodunka, 2016; Pamuła-Behrens, 2018; Seretny, 2018; Szybura, 2016) there is still a lack of practical solutions as to what educators can do in order to facilitate and support their students in this process (Mikulska, 2019a).

Results from the research indicate possible difficulties which Chinese students can encounter during lessons. Apart from communicative problems, they can be misunderstood and judged based on seemingly weird/different behaviours which, in fact, are the effect of cultural differences and a significant stress-inducing factor. Insufficient proficiency in Polish and a lack of knowledge about cultural norms may inhibit Chinese students from socializing with their Polish classmates, as well as hamper communication with teachers.

However, further study is needed in order to verify to what extent these factors are unique for Chinese or Asian students in general, and which aspects can be treated as universal for all students from immigrant backgrounds who attend Polish school.

\section{References}

Auyeung, P., \& Sands, J. (1996). A cross cultural study of the learning style of accounting students. Accounting and Finance, 36(2), 261-274. https://doi.org/10.1111/j.1467-629X.1996.tb00310.x 
Chinese-Polish Joint Stock Shipping Company Chipolbrok. (n.d.). http://chipolbrok.com.pl/

Główny Urząd Statystyczny. (n.d.). https://stat.gov.pl/

Hanwei, L. (2017). Academic integration of mainland Chinese students in Germany. Social Study, 5(1), 80-92. https://doi.org/10.17645/si.v5i1.824

Henze, J., \& Zhu, J. (2012). Current research on Chinese students studying abroad. Research on Comparative and International Education, 7(1), 90-104. https://doi.org/10.2304/rcie.2012.7.1.90

Jóźwiak, I., Piłat, A., Bieniecki, M., Segeš Frelak, J., \& Wysieńska, K. (2013). Migracje społeczności azjatyckich na świecie i do Polski — stan badań i opracowania na temat wybranych krajów. In A. Piłat, J. Segeš Frelak, \& K. Wysieńska (Eds.), Mała Azja w Polsce: Plany i strategie imigrantów z Azji $i$ Bliskiego Wschodu (pp. 11-86). Instytut Spraw Publicznych.

Levchuk, P. (2019). Ukrainian, Polish and Russian trilingualism among Ukrainians of non-Polish origin living in Poland. Cognitive Studies / Études cognitives, 2019(19), Article 1988. https://doi.org/10 $.11649 /$ cs. 1988

Li, X., \& Cutting, J. (2011). Rote learning in Chinese culture: Reflecting active Confucian-based memory strategies. In M. Cortazzi \& L. Jin (Eds.), Researching Chinese learners: Skills, perceptions and intercultural adaptations (pp. 21-42). Palgrave Macmillan. https://doi.org/10.1057/978023029948 $1 \_2$

Malejka, J. (2008). Potomkowie smoka o sobie samych czyli o autostereotypie Chińczyków. Postscriptum Polonistyczne, 2008(1(1)), 207-225.

Majcher-Legawiec, U. (2017). Na przerwie i na lekcji - język specjalistyczny w edukacji dzieci $i$ młodzieży z doświadczeniem migracyjnym. Acta Universitatis Lodziensis: Kształcenie Polonistyczne Cudzoziemców, 24, 243-259. https://doi.org/10.18778/0860-6587.24.18

Malejka, J., \& Gang, Z. (2010). Good morning, China! — czyli o dzień dobry po polsku oraz o niektórych formach adresatywnych. Postscriptum Polonistyczne, 2010(2(6)), 59-66.

Mikulska, A. (2016). Chińskie dziecko w polskiej szkole: Studium przypadku M. In R. Dębski \& W. T. Miodunka (Eds.), Bilingwizm polsko-obcy dziś: Od teorii i metodologii badań do studiów przypadków (pp. 163-176). Księgarnia Akademicka.

Mikulska, A. (2019a). Czego potrzebuje współczesna szkoła wielokulturowa? Polszczyzna jako język szkolnej edukacji — refleksje nauczycieli oddziału przygotowawczego. Języki Obce w Szkole, 2019(1), 62-67.

Mikulska, A. (2019b). Ň̌ hăo bōlán! Chińscy uczniowie w polskiej szkole. Języki Obce w Szkole, 2019(4), 33-42.

Miodunka, W. T. (2016). Glottodydaktyka polonistyczna: Pochodzenie — stan obecny - perspektywy. Księgarnia Akademicka.

Młynarczyk, M. (2013). Artykulacja polskich głosek u chińskich studentów uczących się języka polskiego. Studia Linguistica, 32, 133-145.

Oberg K. (1960). Cultural shock: Adjustment to new cultural environments. Practical Anthropology, 7(4), 177-182. https://doi.org/10.1177/009182966000700405

Pamuła-Behrens, M. (2018). Język edukacji szkolnej w integracyjnym modelu wsparcia ucznia z doświadczeniem migracji w rodzinie. Postscriptum Polonistyczne, 2018(2(22)), 171-186. https://doi.org/ 10.31261/PS_P.2018.22.11

Parris-Kidd, H., \& Barnett, J. (2011). Cultures of learning and student participation: Chinese learners in a multicultural English class in Australia. In M. Cortazzi \& L. Jin (Eds.), Researching Chinese learners: Skills, perceptions and intercultural adaptations (pp. 169-187). Palgrave Macmillan. https: //doi.org/10.1057/9780230299481_8

Rowiński, J., \& Pawłowski, J. (2011). Wizja "państwa” w Chinach. Tradycja a współczesność. In E. Zajdler (Ed.), Zrozumieć Chińczyków: Kulturowe kody społeczności chińskich (pp. 11-34). Wydawnictwo Akademickie Dialog.

Seretny, A. (2018). Język szkolnej edukacji w perspektywie glottodydaktycznej — zarys problematyki. Postscriptum Polonistyczne, 2018(2(22)), 139-156. https://doi.org/10.31261/PS_P.2018.22.09

Sidorowicz, W. (2014). Guanxi — chińska sieć wzajemnych powiązań. Gdańskie Studia Azji Wschodniej, $2014(5), 53-56$.

Szybura, A. (2016). Potrzeby językowe uczniów przybywających z zagranicy w zakresie nauczania języka polskiego. Języki Obce w Szkole, 2016(2), 99-105.

Thøgersen, S. (2016). Chinese students in Europe. European Review, 24(2), 297-305. https://doi.org/ $10.1017 / \mathrm{S} 1062798715000642$ 
Urząd do Spraw Cudzoziemców. (n.d.). Statystyki. http://udsc.gov.pl/statystyki/raporty-okresow e/zestawienia-roczne/

Wardęga J. (2016). Chińczycy — charakterystyka społeczno-kulturowa w kontekście imigracji do Polski. In J. Schmidt \& D. Niedźwiedzki (Eds.), Społeczno-kulturowa identyfikacja cudzoziemców: Raporty $i$ ekspertyzy (pp. 281-352). Wydawnictwo Naukowe Uniwersytetu im. Adama Mickiewicza.

Wardęga, J. (2017). Chińczycy w Polsce — niewidoczna mniejszość. Migration Studies — Review of Polish Diaspora, 2017(2(164)), 121-141.

Zhang, X. (n.d.). Lifelong learning in China: The urgent need to discuss lifelong learning. DPU. http: //edu.au.dk/aktuelt/nyhed/artikel/lifelong-learning-in-china-the-urgent-need-to-discus s-lifelong-learning/

Zhang, X., Liang, X., \& Sun, H. (2013). Individualism-collectivism, private benefits of control, and earnings management: A cross-culture comparison. Journal of Business Ethics, 114(4), 655-664. https://do i.org/10.1007/s10551-013-1711-5

\section{Internet Sources}

Office for Foreigners, Figures for proceedings against foreigners in 2019, http://udsc.gov.pl/statysty $\mathrm{ka} /$ raporty-okresowe/zestawienia-roczne/

http://biuletynmigracyjny.uw.edu.pl/29-maj-2011/polska-nowy-kraj-docelowy-chinczykow

https://businessinsider.com.pl/finanse/makroekonomia/nowy-jedwabny-szlak-najwazniejsza-i nicjatywa-ekonomiczna-chin/2xstct6/

http://chipolbrok.com.pl/

https://stat.gov.pl/

https://stat.gov.pl/files/gfx/portalinformacyjny/pl/defaultaktualnosci/5471/16/1/1/sytua cja_demograficzna_polski_do_2019_r._strona_gus.pdf

http://edu.au.dk/aktuelt/nyhed/artikel/lifelong-learning-in-china-the-urgent-need-to-disc uss-lifelong-learning/

https://www. aseminfoboard.org

This work was financed by the Polish Ministry of Education and Science.

The author declares that she has no competing interests.

a This is an Open Access article distributed under the terms of the Creative Commons Attribution 3.0 PL License (http://creativecommons.org/licenses/by/3.0/pl/), which permits redistribution, commercial and non-commercial, provided that the article is properly cited.

() The Author 2021

Publisher: Institute of Slavic Studies, Polish Academy of Sciences

Publishing history: Received 2020-12-11; Accepted 2021-03-03; Published 2021-10-11. 